\title{
Dead weight loss associated with economic efficiency use of pesticides in Indonesian rice production
}

\author{
Joko Mariyono $^{1}$ \\ ${ }^{1}$ Department of Economics, Universitas Pancasakti Tegal, Indonesia \\ e-mail:mrjoko28@gmail.com
}

\section{Article Info}

Article history:

Received : 7 August 2013

Accepted : 10 January 2014

Published : 1 October 2014

Keywords:

Externalities, welfare, rice,

farm, dead weight loss

JEL Classification:

Q11, Q12, L1.

DOI:

http://dx.doi.org/10.20885/eje m.vol6.iss2.art1

\begin{abstract}
This paper analysis the efficient use of pesticides by internalizing the costs of externality, and estimates the monetary value of welfare loss. The benefit of pesticide use is estimated using a production function, and the economic value of the adverse impact on human health and the environment are represented by a health cost and consumers' willingness to pay for a $\mathrm{kg}$ reduction in pesticide use. To estimate the benefit of pesticides, the paper uses farm level crosssectional and time series data set on rice production. The results indicate low efficiency of using pesticide. This means that totally banning the use of pesticides is economically inefficient.
\end{abstract}

\begin{abstract}
Abstrak
Penelitian ini menganalisis efisiensi penggunaan pestisida dan memperkirakan nilai moneter dari kerugian berupa nilai kesejahteraan yang hilang. Manfaat dari penggunaan pestisida diestimasi dengan menggunakan fungsi produksi, dan nilai ekonomi dari dampak negatif pada kesehatan manusia dan lingkungan diwakili oleh biaya kesehatan dan kesediaan konsumen untuk membayar kerugian akibat penggunaan pestisida. Untuk memperkirakan manfaat tersebut, penelitian ini menggunakan data dari petani yang terlibat pada produksi padi. Hasil penelitian menunjukkan rendahnya efisiensi penggunaan pestisida. Ini berarti penggunaan pestisida tidak efisien secara ekonomi pada produksi padi.
\end{abstract}

\section{Introduction}

Agro-chemical use in agriculture has increased dramatically after implementations of The Green Revolution in in developing countries the 1960s. The use of pesticides is a highly controversial concern because of polarized viewpoints. On one hand, the agricultural sector claims high benefits; and on the other hand, opponents point out the potential and actual risks. The opponents rely on the fact that the global community has a property right to good quality of environment and safe consumer goods.

Growing concern over health risks associated with food products is at the front position of the trade policy debate. Central to this debate is that the "precautionary principle" should be taken against health, safety, and environmental risks, even when science has not established direct causeand-effect relationships (Kelly, 2005). The environmentally sustainable development of a competitive agriculture has become the major goal of agricultural production systems (Reinhard et al., 2002).

Pesticides have adverse impacts on the environment (Pretty and Hine, 2005) and human health (Kishi, 2005). In particular, pesticides have been subject to the Stockholm Convention, meaning that pesticides are considered one of the persistent organic pollutants (Bylehn, 2002). Technically, pesticides have been detected to contaminate soil (Apel et al., 2002; Singh, 
2002) and water resources (Pujara and Khanal, 2002; Schumann, 2002; Toryanikova et al., 2002). Human health relates to the fact that pesticides are synthesized with the sole intention of causing death or harm to living organisms and are developed specifically for their biological activity or toxicity to some forms of life (Cycon, 2013).

Since at the sub-cellular level the organisms have similarity with one another, the uses of pesticides are associated with a certain risk of exposure to not-target living things including human. Human exposure to chemical pesticides may occur occupationally or may occur from any of several involuntary non-occupational sources. The degree of the risk, however, will vary considerably. This is dependent on the intensity and duration of exposure, which in turn, relate to the circumstances under which exposure occurs.

Pesticides give an economic benefit by reducing crops lost to pest attacks. Reduction in pesticide use will lead to decrease in observable yield (Pretty and Waibel, 2005). In spite of the adverse impacts of pesticides on human health and the environment, pesticides are still used widely in agricultural sectors around the world (Pretty and Hine, 2005). One of the reasons for using pesticides is that farmers will earn more because the products are more valuable both in quantity and quality (Farrel, 1998). Many modern farming practices, such as new cultivation techniques, large single cropping, and the new high-yielding crop varieties are made possible mostly by the availability of pesticides (Bond, 1996).

If pesticides still give significant benefits, it will not be optimum to totally prohibit the pesticides because the total positive benefit when no pesticide is used is less than can be attained with some use of pesticides. However, it will not be efficient to let farmers use pesticides without taking the adverse effects into account because society suffers from the adverse impact of pesticides. Since '[the] external environmental and health costs of pesticides are rarely addressed when discussing pesticide use in agriculture' (Pretty and Waibel, 2005: 53), it is therefore required to find a win win solution that fulfils the community's concern for the environment without sacrificing the profitability of agricultural productions.

Negative impacts of pesticide use rapidly became subject to serious criticism after the publication of Rachel Carson's Silent Spring in 1962. With respect to pesticide impact on human health, a distinction has to be made between occupational health hazards and pesticide residues in food products. According to WHO and UNEP, it is estimated that in developing countries there are 1-5 million cases of pesticidepoisoned farmers and 20.000 of the case are deadly (Fleischer, 1999). Gerken et al. (2001) identifies that at least there are four reasons responsible for this: farmers seek medical attention only in cases of serious health problems due to the costs involved; most of the farmers are not aware of the specific symptoms of pesticide poisoning, so health workers are not informed and therefore cannot draw the right conclusions; the system of health statistics does not clearly specify cases of poisoning; in many cases of poisoning or death no further investigations are done due to the lack of technical facilities for autopsies.

Shrestha and Neupane (2002) find that farmers suffered from signs and symptoms of pesticide intoxication after spraying pesticides. In general, farmers do not take care of safety related to pesticide use (Upadhyaya, 2002). Pawukir and Mariyono (2002) empirically find that Indonesian farmers suffer from pesticide intoxication. The number of signs and symptoms is dependent on duration of exposures, toxicity, and volume of pesticides. Houndekon and de Groote (1999) investigate the adverse impact of pesticides used in controlling locusts in Africa. The results show that the pesticide use led to the loss of a large number of livestock. It is also reported that a number of 
people suffered from intoxication. In Thailand, Jungbluth (1996) reports that horticultural product is highly contaminated with pesticides. This resulted in economic losses. Cuyno et al. (2001) state that reductions in pesticide use could provide health and environmental benefit. These studies do not measure the benefits provided by pesticide use, and therefore one of the solutions proposed is to reduce pesticide use.

With regard to the benefits of pesticides, Huang et al. (2003) study pesticide productivity and farmers' health impact of pesticides in Chinese rice agriculture. They found that the pesticides contributed significantly to the farmers' income. But the farmers suffered from poisoning such that they needed to spend more for some medical therapies after applying pesticides. The results suggest that the extra health cost should be subtracted from the farm revenue. With respect to the welfare related to pesticide use, a study in Germany by Waibel and Fleicher (2001) compares the benefit of pesticides with the costs for dealing with agrochemical contamination. The study finds that there are welfare losses because the external costs are not considered costs of production.

With respect to the value of environmental quality and pesticide-reduced residues in agricultural products Mourato et al. (2000) estimate consumers' willingness to pay (WTP) for a reduction in pesticide use. The assumption is that consumers will be willing to pay more for goods if the goods are produced with low or pesticide free. The results of this study imply that the prices of pesticides need some adjustments, because the pesticides reduce the welfare of community. Waibel and Fleischer (2001) conduct an assessment of the economic benefits of pesticide use, which is carried out using the regional factor demand and product supply model. The external cost is calculated from government expenditure on dealing with negative impact of pesticide.
But this study does not determine the recommended reduction in pesticide use.

Ajayi (2000) attempts to find the efficient level of pesticide in Côte d'Ivoire, West Africa. The efficient level of pesticide use is established by internalizing health costs associated with pesticides into production costs. This means that the health cost is considered as extra cost that needs payment. The result shows that an efficient level of pesticide use is determined by taking the health costs into account.

In Indonesia, Suswati and Mariyono (2006), valuate farmers' health during the green revolution in Indonesia. Compared to the value of overall loss of Indonesian farmers estimated by Mariyono (2002) and Suswati et al. (2006), the loss during the green revolution was relatively low. This is because the benefit of pesticides during the green revolution was relatively high even though the use of pesticides during the green revolution was very high. The high use of pesticide was due mostly to huge subsidy (Resosurdarmo and Yamasaki, 2010). A recent study using aggregate data shows that the welfare lost to pesticide use in Indonesian rice production is relatively high since it has accounted for environmentalexternality (Mariyono, 2009).

The previous studies mostly highlighted the impact of pesticide use in agriculture, and proposed some solutions for reducing the use of pesticides and its externalities. The last three studies propose the efficient use of pesticides because they examine that the pesticides still provide benefits for the farmers. These studies also utilize aggregate data, which could be less representative to real condition. Thus, this study is different from the previous ones in terms of farm level data, which is expected to be representing real life. It is expected that this study can find the win-win solution related to pesticide use in Indonesia.

This paper, aims to find the solution by answering the following questions: (1) what is the socially efficient level of pesti- 
cide use after taking into account the adverse impacts? (2) what is the gap between actual and socially efficient use of pesticides? and (3) what is the monetary value of welfare losses associated with the adverse impacts of pesticide use?

\section{Methodology}

\section{Benefit of pesticide use}

The benefit of pesticide use, measured in economic terms, is the expected value of crops lost to pests and/or quality that can be saved or prevented by applying pesticides. It can be approximately derived from a production function. Following Jehle and Reny (2011) a technical production function can be expressed as:

$Y_{i t}=f\left(\mathbf{Z}_{i t}, X_{i t}, T, \varepsilon_{i t}\right)$

where $Y$ is expected value of product, $Z$ is vector of productive inputs including land, $X$ is quantity of pesticides, $T$ is time trend capturing smooth technological progress, $\mathcal{E}$ is random disturbance representing factors such as weather and unpredictable variations in pesticide performance, and subscript $i$ represents region and subscript $\mathrm{t}$ represents year. This means that any given level of inputs will result in an uncertain quantity of output. Since $Y$ is the physical product, the benefit function of pesticide use estimated from the equation (1) is:

$$
B_{i t}=P \cdot f\left(\overline{\mathbf{Z}}_{i t}, X_{i t}, \bar{T}, \varepsilon_{i t}\right)
$$

where $P$ is price of product, $\overline{\mathbf{Z}}$ is average uses of productive inputs, and $\bar{T}$ is average time trend. The interpretation of equation (2) is that given averages use of productive inputs, the expected value of crops lost to pest attacks that can be saved is dependent on the use of pesticides.

\section{Externality and externality costs of pes- ticide use}

Externality is defined as 'the result of an activity that causes incidental benefits or damages to others with no corresponding compensation' (Grafton et al., 2004: 476). With respect to the use of pesticides, Jungbluth (1996: 29) defines negative externalities as "unintentional side effects of pesticide use like ... pesticide residues and health effects'. These can be subdivided into two categories. The first harming the user directly and the second concerning both the user and the society in total. Other external effects that have to be considered for understanding negative externalities are: reduction of biodiversity, health impact and non-agricultural consequences. There are additional costs, called externality costs $(E C)$, resulting from the negative externalities. In this case, the additional cost imposed on farmers is considered as external cost because farmers do not take the costs into account.

However, it is difficult to calculate $E C$ in terms of monetary value, because the externalities are non-marketable. Some methods of valuation of non-marketable goods including environmental amenities have been developed. These methods can be sorted into three groups, based on their reliance on direct market prices, indirect market prices or values, and hypothetical values. The hypothetical value techniques take on a surrogate market approach by directly asking people for their preferences and valuation or making assumptions regarding proxy market conditions and how market agents will behave under different circumstances (Tietenberg and Lewis, 2014).

One of the hypothetical value techniques is a contingent valuation method. This method is conducted using surveys of stakeholders' willingness to pay for a given quality of environmental goods and services. However, doing so is money and time consuming. Thus, it is adequate to adopt the results of similar studies that have been conducted by other researchers to conduct environmental valuation. This approach is called a concept of 'benefit transfer' (Morrison et al., 2002). Even though the reliabil- 
ity and accuracy of this method remains debatable for economic valuations of nonmarket goods (Kristofersson, 2005), it has some important advantages for the policy maker. As, in general, 'benefit transfer's are made across sites as well as over time, the temporal dimension of socioeconomic factors must be taken into account in order to get validity of the 'benefit transfer' (Readey et al., 2004). Rozan (2004) states that if the transfer is used to estimate the benefits in order to conduct an analysis and then to make policy decisions, this 'benefit transfer' could still be acceptable.

\section{Efficient use of pesticides}

Dealing with an efficient use of pesticides needs some mathematical formulations. Suppose a benefit function of pesticides faced by farmers is:

$$
B=g(X)
$$

where $B$ is benefit resulting from using pesticides $\quad X$, with $\partial B / \partial X>0$ and $\partial^{2} B / \partial X^{2}<0$. This means that pesticides provide benefit, and the marginal benefit of pesticides is positive and diminishing. Farmers need to finance the cost of pesticide used. The private cost of pesticides, $P C$, is the amount of pesticides multiplied by its price, $P_{X}$, that is:

$$
P C=X \cdot P_{X}
$$

Thus, the farmers face a problem of net private benefit associated with pesticide use, $N P B$ :

$N P B=B-P C$

Pesticide use leads to external costs, $E C$. Ideally, farmers also need to pay the $E C$ for compensating themselves and community. The $E C$ must be subtracted from the net benefit of pesticide use to obtain a net social benefit NSB (Grafton et al 200 4; Pretty and Waibel, 2005). Therefore, the real problem faced by the farmers is:

$N S B=B-P C-E C$
Following a concept of optimisation postulating that the maximum value of $N S B$ will be obtained if the first derivative of the function is equal to zero (Nicholson, and Snyder, 2011), gives:

$M B=M P C+M E C$

The use of pesticides that meets equation (7) is socially efficient, and results in a maximised value of NSB. Diagrammatically, equation (7) can be drawn in Figure 1 showing that there are three levels of pesticide use that give three distinct levels of NSB.

First, a privately efficient use of pesticides, $X^{*}$, in which the $M B$ is equals to $M C$. This level results in a maximum level of $N P B$. In this case, the externality has not been taken into account, and $N P B$ is then calculated as:

$N P B_{\max }=\int_{0}^{X^{*}}[M B-M C] d X$

If the externality is internalised, NSB resulting from this level of $X^{*}$ is going to be:

$N S B=\int_{0}^{X^{*}}[M B-(M C+M E C)] d X$

Second, a socially efficient use of pesticides, $X^{* *}$, in which $M B$ is equal to $M S C$. This level results in a maximum of $N S B$. The maximum of $N S B$ is calculated as:

$N S B_{\max }=\int_{0}^{X * * *}[M B-(M C+M E C)] d X$

Third, an observed use of pesticides, $X^{o b}$ that results in an current $N S B$, which is calculated as:

$N S B_{\mathrm{ac}}=\int_{0}^{X^{o b}}[M B-(M C+M E C)] d X$

Dead weight loss (DWL) represents the economic value of welfare losses, which is considered the difference between the maximum $N S B$ and the actual $N S B$. 


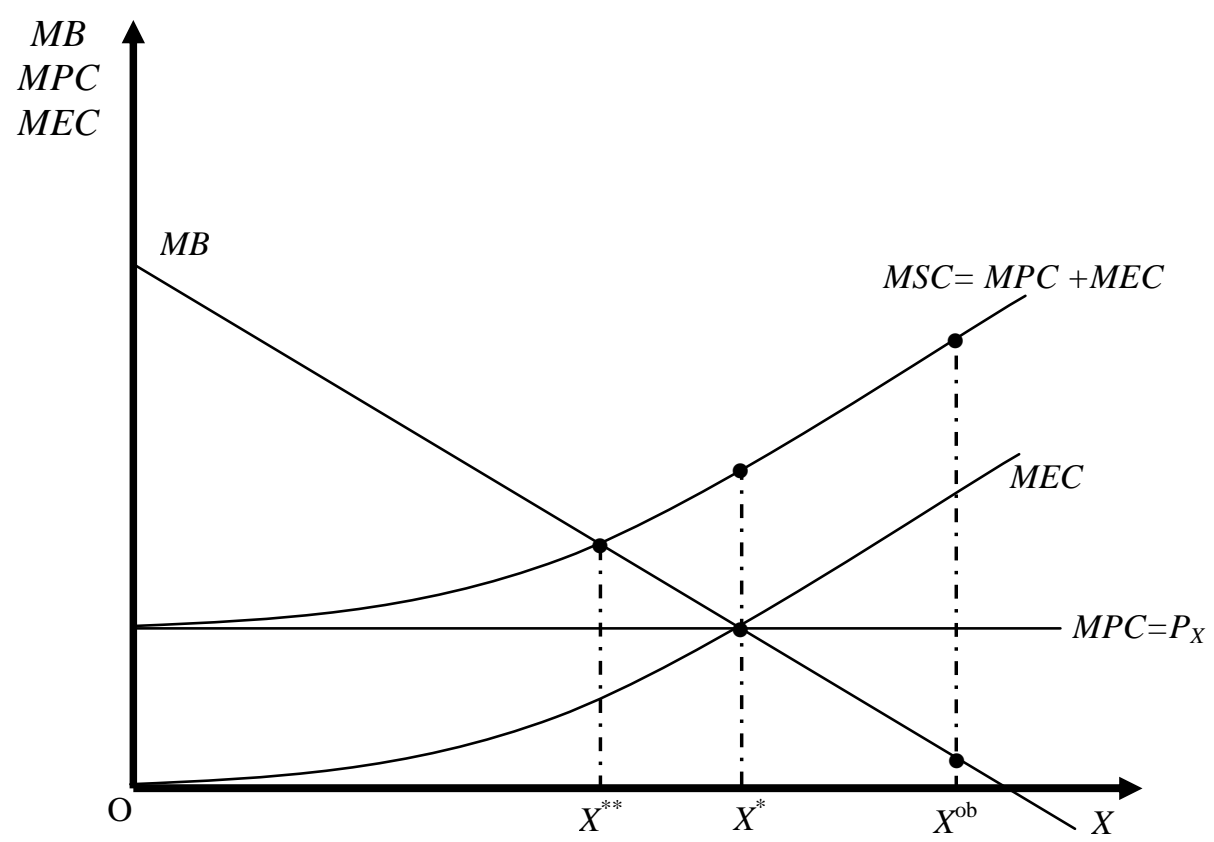

Figure 1: Optimum level of pesticide use

\section{Data source and variable}

The data set used in this study was established from a longitudinal survey conducted by a team of Indonesian research institutions. The data were unbalanced panel data at farm level in 2008, 2010 and 2012. The samples were collected from five regions and farmers cultivating rice were selected using purposive random sampling. For the purpose of this study, the data were aggregated to avoid missing data. The description and measurement of aggregated variables from individual observation are given in Table 1.
Table 2 shows summary statistics for key variables sorted by region. It is important to note that standard deviation of each variable in each region is relatively high, indicating that there is considerable variation in such variables. Table 3 shows the summary statistics for key variables over time. On average, the production increases from time to time. Area, along with materials and chemicals grow overtime. But there is a considerable slowdown in capital use. Labour increases almost two fold in 2010, but decreases in 2012.

Table 1: Data on input and output of rice agriculture and unit measurement

\begin{tabular}{ll}
\hline Variable & Description \\
\hline Production $(Y)$ & production of un husked (kg) \\
\hline Land size $(A)$ & $\begin{array}{l}\text { Total rice-sown area (ha) } \\
\text { Total labour comprises family labours voluntary labours and hired labours. The } \\
\text { labours are used fro six stages of farming (man-working day) }\end{array}$ \\
\hline Capital $(K)$ & $\begin{array}{l}\text { Capital consists of tractor and animal mainly used in land tillage (tractor- } \\
\text { working day) }\end{array}$ \\
\hline Materials $(M)$ & $\begin{array}{l}\text { Total materials used in rice production comprise seed, fertilisers, water irriga- } \\
\text { tion, green manure (monetary term)* }\end{array}$ \\
\hline Pesticides $(X)$ & $\begin{array}{l}\text { Pesticides comprise insecticides, fungicides and herbicides, with solid and liq- } \\
\text { uid formulations (monetary term) } *\end{array}$ \\
\hline
\end{tabular}

Note: *) Monetary value ( $\mathrm{Rp})$ is at 2010 constant price. 
Table 2: Summary statistics for key variables, by region

\begin{tabular}{lrrrrr}
\hline & Lampung & WNT & W\&E Java & N. Sulawesi & S. Sulawesi \\
\hline \multirow{2}{*}{ Production } & 2,477 & 1,341 & 2,482 & 1,284 & 2,450 \\
& $(3,989)$ & $(1,318)$ & $(2,366)$ & $(1,645)$ & $(2,574)$ \\
Land size & 0.5825 & 0.2650 & 0.8038 & 0.5569 & 0.6554 \\
& $(0.6163)$ & $(0.2295)$ & $(0.8020)$ & $(0.6573)$ & $(0.5295)$ \\
Capital & 1.0346 & 2.6686 & 7.3441 & 2.5437 & 2.8108 \\
& $(2.9914)$ & $(3.4090)$ & $(17.0102)$ & $(4.3999)$ & $(9.0604)$ \\
Labour & 61.6450 & 42.3883 & 60.7390 & 30.5603 & 68.0196 \\
& $(67.5690)$ & $(44.1185)$ & $(47.7880)$ & $(24.4477)$ & $(62.5873)$ \\
Materials & 80,260 & 61,349 & 101,200 & 45,605 & 94,452 \\
& $(134,759)$ & $(137,770)$ & $(134,133)$ & $(46,221)$ & $(156,100)$ \\
Pesticides & 56,117 & 13,789 & 26,013 & 22,417 & 38,759 \\
& $(91,057)$ & $(19,559)$ & $(53,899)$ & $(41,441)$ & $(61,900)$ \\
\hline
\end{tabular}

Note: Fgures in the parentheses represent standard deviations. See table 1 for unit measurement; WNT=West Nusa Tenggara.

Source: Author's calculation

Table 3: Summary statistics for key variables, by year

\begin{tabular}{lrrrrrrrr}
\hline \multirow{2}{*}{ Variables } & \multicolumn{2}{c}{2008} & \multicolumn{2}{c}{2010} & \multicolumn{2}{c}{2012} & \multicolumn{2}{c}{ Overall } \\
\cline { 2 - 9 } & \multicolumn{1}{c}{ Mean } & \multicolumn{1}{c}{ Sd. } & \multicolumn{1}{c}{ Mean } & \multicolumn{1}{c}{ Sd. } & \multicolumn{1}{c}{ Mean } & \multicolumn{1}{c}{ Sd. } & \multicolumn{1}{c}{ Mean } & \multicolumn{1}{c}{ Sd. } \\
\hline Production & 1,856 & 1,751 & 2,121 & 2,866 & 3,445 & 3,973 & 2,289 & 2,830 \\
Land size & 0.55 & 0.53 & 0.62 & 0.60 & 0.88 & 0.95 & 0.6461 & 0.6719 \\
Capital & 8.19 & 17.12 & 1.45 & 2.59 & 0.44 & 2.26 & 4.0518 & 11.7521 \\
Labour & 41.69 & 35.34 & 78.99 & 59.79 & 57.77 & 70.29 & 58.96 & 56.19 \\
Materials & 25,219 & 26,909 & 104,472 & 124,573 & 180,220 & 209,864 & 87,340 & 137,237 \\
Pesticides & 12,515 & 32,465 & 40,243 & 66,264 & 69,319 & 92,110 & 34,791 & 65,706 \\
\hline
\end{tabular}

Note: See Table 1 for unit measurement

Source: Author's calculation

\section{Econometric modeling}

According to a statement of Che et al. (2006), the Cobb-Douglas production technology is very fit with agricultural production in Asian developing countries. This study uses the Cobb-Douglas production technology which is commonly expressed as:

$$
Y_{i t}=\bar{A} \mathbf{Z}_{i t}^{a} X_{i t}^{\beta} \exp \left\{\gamma_{1} T+\gamma_{2} T^{2}\right\} \exp \left\{\varepsilon_{i t}\right\}
$$

where $Y_{i t}$ is physical output; $\bar{A}$ is total factor productivity; $\mathbf{Z}_{i t}$ is vector of productive input; $X_{\mathrm{it}}$ is pesticides; $\alpha$ and $\beta$ are elasticity of production with respect to $\mathbf{Z}_{i t}$ and $X$; $T$ is time trend and $\varepsilon$ is random disturbance. ${ }^{1}$ Time trend is included in the model

\footnotetext{
${ }^{1}$ Estimating production functions involving pesticide use is special case, because pesticides are not productive input like fertilizers but they are protective input. It is important to pay attention to the 'actual output as a combination of two com-
}

to capture smooth technological change (Kompas et al., 2004). In terms of double logarithms, the production function is expressed as:

ponents: potential output and losses caused by damaging agents present in the environment' (Lichtenberg and Zilberman, 1986: 262). Pesticides are incorporated in the component of potential loss to pests and are conceptualised in terms of playing a role in reducing benefit losses. Notionally, the proportion of potential yield loss lies between zero and one. This implies that there is a damage function, a kind of cumulative probability distribution. However, the exact probability distribution function of pesticides is still unknown. Ajayi (2000) estimates models with four probability distribution functions. The result indicates that 'the model does not exhibit a conclusive statistical superiority over the other specification models' (Ajayi, 2000: 151). This is a strong indication that pests are always present in the rice agro ecosystem; and therefore pesticides are no longer protective, but curative measure (Sumaryanto et al., 2003). Mariyono (2007) shows that pesticides are used due to the existence of pest infestations. Based on the Ajayi' (2000) results and practical reasons, the functional form in this study is modelled with the usual Cobb-Douglas technology. 


$$
\begin{gathered}
\ln Y_{i t}=\ln \bar{A}+a \ln Z_{i t}+\beta \ln X_{i t} \\
+\gamma_{1} T+\gamma_{2} T^{2}+\varepsilon_{i t}
\end{gathered}
$$

Testing the hypothesis that the pesticide use contributes economic benefit to the farmers is formulated as: $\mathrm{H}_{0}: \beta=0$; and $\mathrm{H}_{1}: \beta>0$.

Following Greene (2011) and Verbeek (2012), a standard econometric method needs to be conducted to estimate the benefit function of pesticide use by estimating a production function. Since there is heteroskedasticity between panels, the production function estimated using panel regression.

\section{Results and Discussion}

\section{Benefits of pesticide use}

The result is given in Table 4. Overall, the production function of rice is significantly estimated. All coefficients on variables used are significantly positive less than unity. The production function shows that Indonesian rice agriculture undergoes a technological regress at a decreasing rate. Based upon the statistical parameters, the use of pesticides has a positive significant effect on the production of rice. This means that pesticides contribute a financial benefit to the farmers in terms of reduction in crops lost to pest attacks.

In terms of a power function or Cobb-Douglas technology, the production function can be expressed as:

$$
\begin{gathered}
\hat{y}_{i t}=3351 \cdot A_{i t}^{0.8054} K_{i t}^{0.0222} L_{i t}^{0.0449} M_{i t}^{0.0547} \\
P_{i t}^{0.0034} \exp \left\{-1.0239 T+0.2938 T^{2}\right\}
\end{gathered}
$$

With average price of rice at $\mathrm{Rp} 1,446.87$ per $\mathrm{kg}$, the benefit function calculated from the production function at the average value of inputs and time trend can be expressed as:

$$
B=1446,87 \cdot 2272.16 \cdot X^{0.0034}
$$

and the marginal benefit of pesticide use evaluated at average levels of inputs:

$$
M B=8,859.95 \cdot X^{-0.9966}
$$

\section{Efficient levels of pesticide use}

There are two levels of efficient use of pesticides. First, a privately efficient level of pesticide use, which is determined when the marginal benefit is equals to the marginal cost of pesticides. Since the pesticide use is measured in monetary value, the price of pesticides has been normalized to unity and the marginal cost of pesticides is unity as well. Solving equation:

$$
8,859.95 \cdot X^{-0.9966}=1
$$

for $X$ results in the privately efficient level of pesticides use, that is, $\operatorname{Rp~9,138.99.~The~}$ observed use of pesticides was Rp 34,791 more than three folds of the privately efficient level. We can see that the use of pesticides was indeed excessive.

Table 4: Production function of Indonesian rice agriculture

\begin{tabular}{lccr}
\hline & Elasticity & Standard error & Z-ratio \\
\hline TFP & 8.1172 & 0.1033 & $78.59^{*}$ \\
Land & 0.8054 & 0.0132 & $61.14^{*}$ \\
Capital & 0.0222 & 0.0010 & $21.52^{*}$ \\
Labour & 0.0449 & 0.0083 & $5.41^{*}$ \\
Materials & 0.0547 & 0.0097 & $5.62^{*}$ \\
Pesticides & 0.0034 & 0.0008 & $4.13^{*}$ \\
$\mathrm{~T}$ & -1.0239 & 0.0688 & $-14.88^{*}$ \\
$\mathrm{~T} * \mathrm{~T}$ & 0.2936 & 0.0175 & $16.82^{*}$ \\
\hline No. of observation & 817 & & \\
Number of group & 358 & & \\
Log-likelihood & -412.60 & & \\
Wald $\chi^{2}(7)$ & $10310.80^{*}$ & & \\
\hline
\end{tabular}

Note: ${ }^{*}$ ) significant at $1 \%$ level

Source: Author's analysis 
Second, a socially efficient level of pesticide use that takes externalities of pesticides into account. The socially efficient level is determined when the marginal benefit of pesticides is equal to the marginal social cost. The marginal social costs consist of a price of pesticides and marginal external costs. In the case of pesticides, the marginal external costs include health cost of farmers, and environmental cost of community. Using the concept of 'benefit transfer', this study adopts an estimated consumers' WTP, which represents health and environmental values (HEV) revealed by community, and an estimated health cost $(H C)$ imposed on farmers. The consumers' WTP has been estimated by Mourato et al. (2000) and the health cost has been estimated by Dung and Dung (2003). Both results of the studies are transferred into this study because of similar characteristics. Related to 'benefit transfer' approach, Rozan (2004) states that even though the goods are similar, the two populations are different in terms of nationality, culture and sensitivity to the environment; the 'benefit transfer' then needs adjustments. The adjustments of consumers' WTP and the health cost are shown in Box 1 and Box 2 (see appendix). By adopting the 'benefit transfer' approach, the farmers' health cost function estimated by Dung and Dung (2003) is:

$H C=2.2595 \cdot P_{X} \cdot X^{0.385}$

and the health and environmental value for reduction in pesticide use estimated by Mourato et al. (2000) is:

$H E V=0.6 \cdot P_{X}$

where $P_{X}$ is the average price of pesticides.

Since the price of pesticides has been normalised to unity, the social cost of pesticides therefore is going to be:

$$
\begin{aligned}
& S C=P C+H E V+H C=X+0.6 \cdot X+ \\
& 2.2595 X^{0.385}
\end{aligned}
$$

The marginal social cost, $M S C$ is:
$M S C=\partial \mathrm{SC} / \partial \mathrm{x}=1.6+0.8699 \cdot \mathrm{X}^{-0.615}$

The efficient use of pesticides can be determined by equalizing the marginal benefit (equation 16) to the marginal social costs (equation 21), that is:

$$
8,859.95 \cdot X^{-0.9966}=1.6+0.8699 \cdot X^{-0.615}
$$

Solving equation (22) using a 'goal seek program' in EXCEL results in the efficient value of pesticide use, that is: $\mathrm{Rp}$ 5,688.81. Compared with the observed level of pesticide use, which is $\mathrm{Rp} 34,791$, the privately efficient level is almost six folds of the socially efficient level. This means that the actual use of pesticides in Indonesia was, on average, much higher than that of both private and social efficient ones. This indicates inefficient use of pesticides.

\section{Dead weight loss associated with ob- served use of pesticides}

Table 5 shows the benefit, social cost, and net social benefit of pesticides at actual, private and social level. The actual $N S B$ resulting from actual level of pesticides use is $\mathrm{Rp} 2,644,392$ per unit of rice farming, and the maximum $N S B$ resulting from the socially efficient level of pesticide use is Rp 2,674,445 per unit rice farming., ${ }^{2,3}$ Therefore, the economic value of welfare losses resulting from the actual use of pesticides is $\mathrm{Rp} 30,053$ per unit farming.

\footnotetext{
${ }^{2}$ The maximum NSB is calculated using the value of $\int_{0}^{5688}\left[M B-P_{X}-M E C\right] d X$

${ }^{3}$ The actual NSB is calculated using the value of $\int_{0}^{34791}\left[M B-P_{X}-M E C\right] d X$
} 
Table 5: Net social benefit of pesticide use

\begin{tabular}{crccc}
\hline Condition & Pesticide Value & Benefit & Social Cost & NSB \\
\hline Actual & 34,791 & $2,700,184$ & 55,792 & $2,644,392$ \\
Private & 9,139 & $2,687,939$ & 14,698 & $2,673,241$ \\
Social & 5,688 & $2,683,609$ & 9,164 & $2,674,445$ \\
\hline \multicolumn{5}{c}{ DWL $\left(N S B_{\text {actual }}-N S B_{\text {social }}\right)=$} \\
\hline
\end{tabular}

Source: Author's calculation

DWL exists because the existing level of pesticides use exceeds the efficient level. The economic value of DWL was almost similar to the value of pesticides, even though the value resulting from inefficient use of pesticides at farm level was relatively small compared to the net social benefit. However, at national level, it could be very significant value. In this sample of study, the average size of rice farming was 0.6719ha. At national level, total riceplanted area was approximately 13,253,450ha. This means that there were around 19,725,331 units of rice farming. Let us assume that on average there are two growing seasons of rice a year. Thus the DWL at national level was roughly $\mathrm{Rp}$ $1,185,610,754,130$ a year.

At national level, the DWL was relatively significant. Compare to a previous study using aggregate data by Mariyono (2009), the value estimated using farm level data is quite higher. As expected that farm level data represent closer to the real condition than aggregate data, the current result can be used as better reference. The value will not impose the society if the pes-

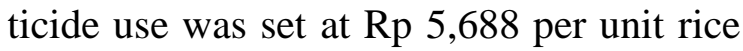
farming. It has not been too late to improve welfare's societies by reducing pesticide use to the socially efficient level.

However, it is not a simple task to reduce the pollution because it is non-point source pollution, i.e.: a form of pollution whose source and quantity are difficult to identify (Grafton et al., 2004). The objective of pesticide policy at national level should bring the social costs in line with social benefits. Some economic instruments, for example taxes, registration fees and import duties, work to redistribute the costs of pesticide use from the public to pesticide producers and consumers and adjust the private costs to the total social costs occurring for pesticide use (Tietenberg and Lewis, 2014). The environmental tax, for example, is not only expected to diminish demand for pollutants but also provides government revenue. The tax-revenue can then be allocated to compensate health costs and other adverse impacts on environment.

Adopting ecological technology, such as integrated pest management (IPM), is another alternative for reducing pesticides without significant reduction in production (Pretty and Waibel, 2005). Integrated pest management (IPM) programme in Indonesia shows how the aggregate level of pesticide use can be diminished (AgroChemical Report, 2003; Mariyono et al., 2002; Mariyono et al., 2003). With better agronomical and cultural techniques and suitable analyses, production can be enhanced with lower level of chemical inputs including pesticides (Mariyono, 2006).

\section{Conclusion}

Rice production has caused environmental pollution, particularly non-point-source pollution because the production releases pesticides into the environment. The pesticides are capable of polluting the environment since they are poisonous. As a consequence, if pesticides contaminate the agricultural product, they can harm the consumers. Furthermore, there is pesticide exposure to the farmers when they are applying the pesticides. Rice production has 
caused negative externalities that not only impose on the farmers, but also on the community.

Along with the global concern about the quality of environment, the agricultural practices with high use of pesticides are no longer fashionable. This is because the global community has had a property right to higher quality of environment and harmless consumer goods and services, and farmers need to be protected from severe pesticide exposure. It is therefore crucial to deal with pesticide externalities. However prohibiting use of pesticides is not a good decision, if pesticides still provide economic benefit. Consequently, an efficient level of pesticide use needs to be estimated to identify whether or not pesticides are overused.

Using a Cobb-Douglas production technology, the benefit of pesticide use is econometrically estimated. The efficient level of pesticide use is then calculated by equalizing the marginal benefit to the marginal social cost, which consists of private costs and externality costs. This level of pesticide use is the optimal trade off in which net social benefit of pesticide is maximized. If the actual level of pesticide is the same as the efficient one, the farmers and the community will be in to some extent ideal condition. From the calculation in fact, it is found that the efficient level of pesticide use is much lower than that of actual level. This indicates that the pesticide use is inefficient, that is, the actual use of pesticides is above the socially efficient level. In other words, farmers and community suffer from the adverse impacts of pesticides and there exist welfare losses.

In this case, the economic value of welfare losses is relatively low compared with the social benefit resulting from the actual use of pesticides. This is because the use of pesticides provides substantial benefits to the farmers. However, it does not mean that the use of pesticides should be uncontrolled. In spite of relatively low wel- fare loss, reducing use of pesticides will increase the level of the community's welfare. Scaling up at national level the economic value of welfare losses is very high. Hence, reducing the use of pesticides to an efficient level is the win-win solution. Farmers will be better off in terms of higher net social benefit, and community will also be better off resulting from availability of healthier products and better environmental quality.

\section{References}

Agro-Chemical Report (2003) Pesticide and policy: The Impact of Integrated Pest Management (IPM) on The Indonesian Economy, Agre Chemical Report, 2, 18-20.

Ajayi, O.O.C. (2000) Pesticide Use Practices, Productivity and Farmers' Health: The Case of Cotton-Rice Systems in Côte d'Ivoire, West Africa, Pesticide Policy Project Publication Series, Special Issue $3 A$.

Apel, H., Paudyal, M.S. and Richter, O. (2002) Environmental Risk Assessment of Pesticide Use Based on The Modeling of The Environmental Fate of Pesticides on Soil, in Proc. Int. Workshop on Environmental Risk Assessment of Pesticides and Integrated Pesticide Management in Developing Countries 6-9 Nov. 2001 Kathmandu, Nepal (Eds.) A. Herrmann and S. Schumann, Landschaftsökologie und Umweltforschung 38, Braunschweig, pp.13-23.

Bond, J.W. (1996) How EC and World Bank Policies are Destroying Agriculture and the Environment. AgBé Publishing: Singapore.

Bylehn, A. S. (2002) The Stockholm Convention on Persistent Organic Pollutants (POPs) and UNEP Activities on POPs pesticides, in Proc. Int. 
Workshop on Environmental Risk Assessment of Pesticides and Integrated Pesticide Management in Developing Countries 6-9 Nov. 2001 Kathmandu, Nepal (Eds) A. Herrmann and S. Schumann, Landschaftsökologie und Umweltforschung 38, Braunschweig, pp. 245249.

Che, T.N., Kompas, T., and Vousden, N. (2006) Market Reform, Incentives and Economic Development in Vietnamese Rice Rroduction, Comparative Economic Studies, 48, 277301.

Cuyno, L.C.M., Norton , G.W. and Rola, A. (2001) Economic Analysis of Environmental Benefits of Integrated Pest Management: A Philippine Case Study, Agricultural Economics, 25, 227-233.

Cycon, S.M.K. (2013). Fertile lands and bodies: connecting the Green Revolution, pesticides, and women's reproductive health. Pitzer Senior Theses. Paper 38.

Dung, N. H. and Dung, T. T. T. (2003) Economic and Health Consequences of Pesticide Use in Paddy Production in the Mekong Delta, Vietnam. EEPSEA-Research Reports. On WWW at http://203.116.43.77/publications/re search1/ACF124.html [170706].

Farrel, M. (1998) Small Company Imports Have Great Impact, Business, NovDec, 1-2.

Fleischer, G. (1999) The Role of Economic Analysis of Pesticide Use and Policy Experiences from Country Case Studies, Publication of the Pesticide Policy Project, Special Issue 1, 208222.

Gerken, A., Suglo, J. and Braun, M. (2001) Pesticides Use and Policies in Gha- na: An Economic and Institutional Analysis of Current Practice and Factors Influencing Pesticide Use, $A$ Publication of the Pesticide Policy Project, 10, 1-30

Grafton, R.Q., Adamowicz, W., Dupont, D., Nelson, H., Hill, R.J. and Renzetti, S. (2004) The Economics of the Environment and Natural Resources. Blackwell Publishing: Carlton.

Greene, W.H. (2011) Econometric Analysis. $7^{\text {th }}$ Edition. Prentice Hall: New Jersey.

Houndekon, V. and de Groote, H. (1998) Health Costs and Externalities of Pesticides Application in Locust and Grasshopper Control in the Sahel. Paper prepared for the Annual conference of the American Agricultural Economics Association, 2-5 August 1998, Utah.

Huang, J., Qiao, F., Zhang, L. and Rozelle, S. (2003) Farm Pesticide, Rice Production, and Human Health. EEPSEA-Research Reports. On WWW at

http://203.116.43.77/publications/re search1/ACF268.html [170706].

Jehle, G. A. and Reny, P. J. (2011) Advanced Microeconomic Theory. Addison-Wesley: Boston.

Jungbluth, F. (1996) Crop Protection Policy in Thailand: Economic and Political Factors Influencing Pesticide Use. Pesticide Policy Project Publication Series, 5, 1-29.

Kelly, L. (2005) The Global Integrated Pest Management Facility Addressing Challenges of Globalization: An Independent Evaluation of the World Bank's Approach to Global Programs. The World Bank Operations Evaluation Department. 
Kishi, M. (2005) The Health Impacts of Pesticides: What Do We Now Know? in The Pesticide Detox: Towards A More Sustainable Agriculture (Ed). N. J. Pretty, Earthscan: London, pp.23-40.

Kompas, T., Che. T. N., and Grafton, R.Q. (2004) Technical efficiency effects of input control: evidence from Australia's banana prawn fishery. Applied Economics 36, 1631-1641.

Kristofersson, D. and Navrud, S. (2005) Validity Tests of Benefit Transfer: Are We Performing the Wrong Tests?, Environmental and Resource Economics 30, 279-286

Lichtenberg, E. and Zilberman, D. (1986) The econometrics of damage control: Why specification matters. American Journal of Agricultural Economics, 68, 261-273.

Mariyono, J. (2002) Valuasi Ekonomi Kehilangan Manfaat Bersih Akibat Biaya Kesehatan Penggunaan Pestisida Kimia, Jurnal Manusia dan Lingkungan, 9, 16-23.

Mariyono, J. (2006) Technological Change and Environmental Protection in Agricultural Development: Can Economic and Ecological Reason be a Synergism?, Jurnal Ekonomi Pembangunan, 7, 1-16.

Mariyono, J. (2007) The Impact of IPM Training on Farmers' Subjective Estimates of Economic Thresholds for Soybean Pests in Central Java, Indonesia, International Journal of Pest Management, 53, 83-87.

Mariyono, J. (2009) Socially Inefficient Use of Pesticides due to Negative Externalities: A Case of Indonesian Rice Agriculture, International Journal of Ecology and Development, 13, 93-107.
Mariyono, J., \& Bhattarai, M. (2009). Chili Production Practices in Central Java, Indonesia: A Baseline Report. AVRDE The World Vegetable Center, Taiwan.

Mariyono, J., Irham and Suratiyah, K. (2002) Dampak Teknologi Pengendalian Hama Terpadu pada Permintaan Pestisida pada Padi di Yogyakarta, Agrosains, 15, 141-149.

Mariyono, J., Pawukir, E.S. and Setyoko, H. (2003) Economic Incentive of Field Management Training for Soybean Producers in East Java, Jurnal Agribisnis, 7, 1-10.

Morrison, M., Bennet, J., Blamey, R., and Louviere, J. (2002) Choice Modeling and Tests of Benefit Transfer, American Journal of Agricultural Economics, 84, 161-170.

Mourato, S., Ozdemiroglu, E. and Foster, V. (2000) Evaluating Health and Environmental Impacts of Pesticide Use: Implications for The Design of Ecolabels and Pesticide Taxes. Environmental Science and Technology, 34, 1456-1461.

Nicholson, W. and Snyder, C.M. (2011). Microeconomics Theory: Basic Principles and Extensions, Cengage Learning, Boston.

Pawukir, E. S. and Mariyono, J. (2002) Hubungan antara Penggunaan Pestisida dan Dampak Kesehatan: Studi Kasus di Dataran Tinggi Alahan Panjang Sumatera Barat, Jurnal Manusia dan Lingkungan, 9, 126136.

Pretty, J. and Hine, R. (2005) Pesticide Use and the Environment, in The Pesticide Detox: Towards a More Sustainable Agriculture (ed.) J.N. Pretty, Earthscan: London, pp. 1-22.

Pretty, J. and Waibel, H., (2005) Paying the Price: The Full Cost of Pesticides. 
in The Pesticide Detox: Towards a More Sustainable Agriculture (ed.) J.N. Pretty, Earthscan: London, pp. $39-54$.

Pujara, D.S. and Khanal, N. R. (2002) Use of Pesticides in Jaishidihi Subcatchment, Jhikhu Khola Watershed, Middle Mountain in Nepal, in Proc. Int. Workshop on Environmental Risk Assessment of Pesticides and Integrated Pesticide Management in Developing Countries 6-9 Nov. 2001 Kathmandu, Nepal (Eds.) A. Herrmann and S. Schumann, Landschaftsökologie und Umweltforschung 38, Braunschweig, pp. 168-177.

Ready, R. Navrud, S., Day, B., Dubourg, R., Machado, F., Mourato, S., Spanninks, F., and Rodriquez, M.X.V. (2004) Benefit Transfer in Europe: How Reliable are Transfers between Countries? Environmental and Resource Economics, 29, 6782.

Reinhard, S., Lovell, C.A. and Thijssen, G. (2002) Analysis of Environmental Efficiency Variation. American Journal of Agricultural Economics, 84, 1054-1065.

Resosudarmo, B.P. and Yamazaki, S. (2010). "Training and visit $(\mathrm{T} \& \mathrm{~V})$ vs. farmer field school: the Indonesia's experience", in: V. Beckmann, N.H. Dung, X. Xi, M. Spoor, and J. Wesseler (eds.) Economic Transition and Natural Resource Management in South East Asia. Shaker Verlag, Aachen, pp. 269-295.

Rozan, A. (2004) Benefit Transfer: A Comparison of WTP for Air Quality between France and Germany, Environmental and Resource Economics, 29, 295-306.

Schumann, S. (2002) Fast Estimation of Pesticide Risk Potential on
Groundwater through the Use of a Dye Tracing Technique, in Proc. Int. Workshop on Environmental Risk Assessment of Pesticides and Integrated Pesticide Management in Developing Countries 6-9 Nov. 2001 Kathmandu, Nepal (Eds.) A. Herrmann and S. Schumann, Landschaftsökologie und Umweltforschung 38, Braunschweig, pp. 178189.

Shrestha, P. L. and Neupane, F.P. (2002) Socio-economic Contexts on Pesticide Use in Nepal, in Proc. Int. Workshop on Environmental Risk Assessment of Pesticides and Integrated Pesticide Management in Developing Countries 6-9 Nov. 2001 Kathmandu, Nepal (Eds.) A. Herrmann and S. Schumann, Landschaftsökologie und Umweltforschung 38, Braunschweig, pp. 205223

Singh, A. (2002) Modeling Overland Flow and Sediment Discharge from Agricultural Lands on Himalayan Foot Hills under Monsoon Conditions, in Proc. Int. Workshop on Environmental Risk Assessment of Pesticides and Integrated Pesticide Management in Developing Countries 6-9 Nov. 2001 Kathmandu, Nepal (Eds.) A. Herrmann and S. Schumann, Landschaftsökologie und Umweltforschung 38, Braunschweig, pp. 224-235.

Sumaryanto, W. and Siregar, M. (2003) Determinan Efisiensi Teknis Usahatani Padi di Lahan Sawah Irigasi, Jurnal Agroekonomi, 21, 72-96.

Suswati, E. and Mariyono, J. (2006) Nilai Ekonomi Kesehatan Petani yang Ditimbulkan selama Revolusi Hijau di Indonesia: Studi Dampak Kesehatan, Jurnal Administrasi dan Kebijakan Kesehatan, 4,7-14. 
Suswati, E., Agustin, N.K. and Mariyono, J. (2006) Adverse Health Impacts of Pesticide Use on Indonesian Rice Production: An Economic Analysis, SOCA, Jurnal Sosial Ekonomi Pertanian dan Agribisnis, 6, 127-133.

Tietenberg, T. and Lewis, L. (2014) Environmental \& Natural Resource Economics. 10 ${ }^{\text {th }}$ Edition. Pearson Addison Wesley: Boston.

Toryanikova, R.V., Karaseva, T.A., Lutsenko, O.A. and Nishonov, E. (2002) The Dynamics of Herbicides in The Water Environment of Uzbekistan, in Proc. Int. Workshop on Environmental Risk Assessment of Pesticides and Integrated Pesticide Management in Developing Countries 6-9 Nov. 2001 Kathmandu, Nepal (Eds) A. Herrmann and S. Schumann, Landschaftsökologie und Umweltforschung 38, Braunschweig, pp. 250-255.
Upadhyaya, N.S. (2002) Experience of Community IPM in Nepal, in Proc. Int. Workshop on Environmental Risk Assessment of Pesticides and Integrated Pesticide Management in Developing Countries 6-9 Nov. 2001 Kathmandu, Nepal (Eds) A. Herrmann and S. Schumann, Landschaftsökologie und Umweltforschung 38, Braunschweig, pp. 256264.

Verbeek, M. (2012) A Guide to Modern Econometrics, $4^{\text {th }}$ Edition, John Wiley \& Sons, LTD: Chichester.

Waibel, H. and Fleischer, G. (2001) Experience with Cost Benefit Studies of Pesticides in Germany. Paper presented at the OECD workshop on the Economics of Pesticide Risk Reduction in Agriculture Copenhagen, Denmark November 28-30th, 2001. 


\section{Appendix}

Box 1. Derivation of consumers' WTP for reducing pesticide use

Mourato et al. (2000) estimate a willingness to pay (WTP) using a contingent ranking approach, a variant of the standard contingent valuation method, which is capable of tackling the multidimensional effects associated with pesticide applications.

The overall WTP per loaf for the protection of human health and the environment is $(£ 0.007+\boldsymbol{E}$ $0.053=\$ 0.06)$. It would be aggregated over the 160 loaves purchased on average each year by the U.K.'s 20 million households. This aggregated marginal WTP would then be divided by the total 15 million $\mathrm{kg}$ of pesticides used in cereal crops in the U.K. to obtain an external value of $f$ $12.59 / \mathrm{kg}$ of pesticide. Compared with a current average price of pesticides $\left(P_{X}\right)$, which is $f 20 / \mathrm{kg}$, this would represent a value of over $60 \%$.

From this calculation, the health and environmental value $(H E V)$ of a kilogram of pesticides used in agriculture is:

$$
H E V=0.6 \cdot P_{X}
$$

Source : Mourato, S., Ozdemiroglu, E. and Foster, V. (2000) Evaluating health and environmental

Box 2. Derivation of health cost associated with pesticide use

Dung and Dung (2003) estimate a health cost function associated with pesticides use in Vietnam. The health cost computation is based upon the medical examinations. A medical team of doctor, nurse and an X-ray technician, and a medical technologist conduct the medical examinations. These examinations provide an assessment of each farmer's illness and their seriousness. Medical treatments needed to restore the farmer's health are assessed. The treatment cost including medication and doctor's fees and time loss in recovery of farmer's health is then used as a measure of health cost.

The health cost function, estimated in local currency (VDN), is:

$$
H C=0.65 \cdot A G E^{1.41} \cdot \mathrm{e}^{0.72 D R I N K} X^{0.385}
$$

where $X$ is total pesticide use.

Based on average conditions of Vietnamese farmers', health cost is:

$$
H C=869.91 \cdot X^{0.385}
$$

At the same time, the cost of pesticides in Vietnam is 385 VDN

Converted to the price of pesticides, $P_{X}$, the health cost is going to be:

$$
H C=2.2595 \cdot P_{X} \cdot X^{0.385}
$$

The health cost is then adjusted with the price of pesticides in Indonesia.

Source: Dung, N. H and Dung, T. T. T. (2003) Economic and health consequences of pesticide use in paddy production in the Mekong Delta, Vietnam. EEPSEA-Research Reports. On WWW at http://203.116.43.77/publications/research1/ACF124.html 